\title{
LITERATURE
}

1. Glazychev V. Essays on Design Theory and Practice in the West [Text] / V. Glazychev - M.: Art, 1970. - 108 p.

2. Degtyanikova N. Heuristic methods in the study of the composition of works of art: avtoref. thesis. ... Ph.D. in History of Arts / N. Degtyanikova - Jour., 2004. - 20 p.

3. Ikonnikov A. Space and form in architecture and urban planning [Text] / A. Ikonnikov - M.: «КомКniga», 2006. - $176 \mathrm{p}$.

4. Koveshnikova N. Design. History and Theory [Text] / N. Koveshnikova N. - M.: Omega -L, 2009. - 224 p. - ISBN: 978-5-370-01250-1.

5. Stepanova S. The aspect of visual perception in the architectural space of the city as a contribution to the development of cross-border cooperation in the Asia-Pacific region: materials of the international scientific-practical conference dedicated to the 65th anniversary of the Khabarovsk-Krai one-day formation "Development of interactions in the legal and economic space of the Asia-Pacific countries: Formal and informal aspects". - Khabarovsk: RICHGAEP, 2003. 323 p. - C. 91-93.

6 Stepanova S. Visual image of the modern city environment (statement of the problem): materials of the scientific conference of the faculty and young scientists dedicated to the 70th anniversary of the Moscow Architectural Institute, abstracts of papers "Architectural Science and Education". $286 \mathrm{p}$.

7. Kudin P. Psychology of Perception and Poster Art / P. Kudin, B. Lomov, A. Mytkin. -M.: Post, 1987. -208 p.

8. Sheluh S. Artistic image and composition in the design of furniture of the period of the XVIII early XXI centuries: aftoref. thesis. ... Ph.D. in History of Arts / S. Sheluh. . - M., 2005.

$-26 \mathrm{p}$.

9. Shymko V. Architectural and design design. Fundamentals of the theory (environmental approach) / V. Shymko - M.: Arhitecture C, 2009. - 219 p.

10. Shymko V Architectural and design design of the urban environment / V. Shymko - M.:

Arhitecture C, 2006. - 127 p.

11. The design of the future century. [Electronic resource] - http://www.ielastic.ru/

12. Morhun N. Architectural scenography of the urban environment as a design strategy for the reconstruction of the historic city center and a factor in strengthening its tourist image /

N. Morhun, L. Reznyckaya, A. Skopyncev - article UAO, Rostov-na-Dony, Russia.

UDC 711.04 doi: 10.31650/2519-4208-2020-20-263-271

\section{ARCHITECTURAL LIGHTING OF THE INTERIOR SPACES OF RESIDENTIAL AND PUBLIC BUILDINGS (LIGHT COMFORT)}

Vasylenko O., Doctor of Architecture, Professor, Department of architect design e-mail: abvasilenko10@gmail.com,ORCID:0000-0002-8261-3104

Mykhailenko O., assistant of the Department Design of Architectural Environment Shmarev I., Master of Architecture and Urban Planning, Department of architect design Tanirverdiyev A., Master of Architecture and Urban Planning, Department of architect design Odessa State Academy of Civil Engineering and Architecture, Ukraine tel. 096-770-15-68

Abstract: The paper identified the main aspects of the natural lighting of interior spaces of residential and public buildings, affecting the light forms of education, the quality of light, visual comfort, visual discomfort, uneven illumination, and so on. 
The quality of architecture as a visual art is mainly evaluated because of visual impressions that are possible only in the presence of light. The modern period of development of society is characterized by objective civilized processes of global urbanization, as a result of which architecture itself becomes a cause of a disturbance in the state of balance of the environment for human life and the cause of the ecological crisis. It is known that under the influence of such anthropogenic factors as a decrease in the transparency of the atmosphere due to the growth of cities and industry, insolation resources are changing in residential areas. In the framework of the concept of an urban-ecological approach in the formation of the human environment, the problems of creating a comfortable bioclimatic architecture or ecological buildings that allow the multilateral use of the energy of the Sun are highlighted.

Among the factors determining the quality of the environment, an important place is occupied by the natural light environment, which largely depends on the nature of the light climate. Sunlight has a comprehensive impact on all major categories of architecture, including light comfort, durability, expressiveness, and economy. The appropriate level and quality of lighting in rooms and urban areas is an important prerequisite for creating light comfortable living conditions for a person, contributes to his creative activity, increase labor productivity and improve leisure conditions. The parameters of the light environment are one of the main elements that form the microclimate of the premises.

In many developed countries, in connection with the expansion of megacities, the issue of not only functional, but also visual aesthetic comfort of the environment is becoming relevant. Creating a light environment that meets the practical, psychological and aesthetic requirements of the people who live in it is one of the most important tasks of an architect. Knowledge of the basic compositional properties of lighting, the ways of its rational use in architecture, and the possession of methodological skills in architectural design contribute to the successful solution of this problem. Lighting conditions determine the correct perception of the compositional rhythm, the proportions and depth of the premises, plastics and color finishes of the surface.

The concept of a light environment includes the integral coordination of the components of natural and artificial lighting, considered in unity and interaction. The progressive reception of integrated (combined) lighting is dictated by social need and is reflected in improving the quality of lighting and in saving resources for the design and construction of buildings and structures.

Modern advances in the field of fundamental and natural sciences allow us to improve the methods and means of research and forecasting in the knowledge of the complex interaction of man and the environment. The main task is to optimize the light environment in architecture with the rational use of energy and natural resources.

The analysis of scientific works and design practice of architectural firms of Ukraine allowed us to identify a number of unresolved issues (in the aspect of accounting and solving the problem of the comfort of the lighting environment in architecture): 1) black-and-white shaping as a specific tool for architectural composition to achieve plastic expressiveness and as a tool for the architect's creativity; 2) in the process of developing the facades of buildings for various purposes, the relation to the functional and formative function of light is traced; 3 ) the effect of sunlight on interior spaces; 4) the effect of sunlight on residents in high-rise residential buildings. The problem of creating a comfortable lighting environment in European architecture has not been comprehensively considered to date, which served as the basis for analysis and discussion in this work.

The comfort of the light environment is lighting, it is the light formation of the interior spaces of architectural objects. The comfort of the lighting environment can satisfy people in the interior according to many requirements, divided into qualitative and quantitative categories.

Quantitative categories are determined by the level of necessary illumination. Qualitative categories are determined by the spectral composition of light and its distribution in space. 
Along with the change in visual functions achieved by direct measurements, the presence in the field of view of spots with a brightness significantly higher than the brightness of adaptation can cause sensations called discomfort. Building norms and rules of Ukraine define visual discomfort as a feeling of inconvenience or tension.

The information obtained through vision is needed by a person in order to take note of it and it is necessary to justify practical activities and to control the production process. In production, it is necessary to create conditions that are as favorable as possible for visual work, i.e. First of all, comfortable and fairly intense lighting when designing an architectural environment, taking into account visual comfort.

Key words: comfort, light environment, visual comfort, discomfort, the principles of the light forms of education.

\section{АРХИТЕКТУРНОЕ ОСВЕЩЕНИЕ ВНУТРЕННИХ ПРОСТРАНСТВ ЖИЛЫХ И ОБЩЕСТВЕННЫХ ЗДАНИЙ (СВЕТОВОЙ КОМФОРТ)}

Василенко А. Б., доктор архитектуры, профессор кафедры дизайна архитектурной среды e-mail: abvasilenko10@gmail.com,ORCID:0000-0002-8261-3104

Михайленко О. С., ассистент кафедры дизайна архитектурной среды

Шмарев И. П., магистр архитектуры кафедры дизайна архитектурной среды

Танирвердиев А. Д., магистр архитектуры кафедры дизайна архитектурной среды

Одесская государственная академия строительства и архитектуры, Украина

tel. 096-770-15-68

Аннотация: В работе выявлены основные аспекты естественного освещения внутренних пространств жилых и общественных зданий, влияющие на светоформообразование, качество освещения, зрительный комфорт, зрительный дискомфорт, неравномерность освещения и т.д.

Качество архитектуры как визуальное искусство преимущественно оценивается на основе зрительных впечатлений, возможных лишь при наличии света. Современный период развития общества характеризуется объективными цивилизованными процессами глобальной урбанизации, в результате чего сама архитектура становится причиной нарушения состояния сбалансированности среды для жизнедеятельности человека и причиной экологического кризиса. Известно, что под действием таких антропогенных факторов, как снижение прозрачности атмосферы в связи с ростом городов и промышленности, происходят изменения инсоляционных ресурсов на селитебных территориях. В рамках концепции урбоэкологического подхода в формировании среды жизнедеятельности человека, на первый план выдвигаются проблемы создания комфортной биоклиматической архитектуры или экологических зданий, позволяющих многосторонне использовать энергию Солнца.

Среди факторов, определяющих качество среды, важное место занимает естественная световая среда, которая во многом зависит от характера светового климата. Солнечный свет оказывает всеобъемлющее влияние на все основные категории архитектуры, включая световую комфортность, долговечность, выразительность, экономичность. Соответствующий уровень и качество освещения помещений и урбанизированных территорий является важной предпосылкой создания световых комфортных условий жизнедеятельности человека, способствует его творческой активности, повышению производительности труда и улучшению условий отдыха. Параметры световой среды являются одними из основных элементов, которые формируют микроклимат помещений.

Во многих развитых странах в связи с расширением мегаполисов актуализируется вопрос не только функциональной, но и визуальной эстетической комфортности среды. Создание световой среды, отвечающей практическим, психологическим и эстетическим 
требованиям пребывающих в ней людей, - это одна из важнейших задач архитектора. Знание основных композиционных свойств освещения, способов его рационального использования в зодчестве, владение методическими навыками архитектурного проектирования способствует успешному решению этой задачи. Условия освещенности определяют правильное восприятие композиционного ритма, пропорций и глубины помещений, пластики и цветовой отделки поверхности.

Понятие световой среды включает интегральное согласование компонентов естественного и искусственного освещения, рассматриваемое в единстве и взаимодействии. Прогрессивный приём интегрального (совмещённого) освещения диктуется социальной потребностью и находит отражение в улучшении качества освещения и в экономии ресурсов на проектирование и строительство зданий и сооружений.

Современные достижения в области фундаментальных и естественных наук позволяют совершенствовать методы и средства исследований и прогнозирования в познании сложного взаимодействия человека и среды. Главной задачей является оптимизация световой среды в архитектуре при рациональном использовании энергетических и природных ресурсов.

Ключевые слова: комфорт, световая среда, зрительный комфорт, дискомфорт, принципы светового образования формы.

\title{
АРХІТЕКТУРНЕ ОСВІТЛЕННЯ ВНУТРІШНІХ ПРОСТОРІВ ЖИТЛОВИХ І ГРОМАДСЬКИХ БУДІВЕЛЬ (СВІТОВИЙ КОМФОРТ)
}

\author{
Василенко О. Б., доктор архітектури, професор кафедри дизайну архітектурного \\ середовища \\ e-mail: abvasilenko10@gmail.com,ORCID:0000-0002-8261-3104
}

Михайленко О. С., асистент кафедри дизайну архітектурного середовища

Шмарьов І. П., магістр архітектури та містобудування кафедри дизайну архітектурного середовища

Танірвердисв А. Д., магістр архітектури та містобудування кафедри дизайну архітектурного середовища

Одеська державна академія будівництва та архітектури, Україна

096-770-15-68

Анотація: В роботі виявлені основні аспекти природного освітлення внутрішніх просторів житлових і громадських будівель, що впливають на світлоформоутворення, якість освітлення, зоровий комфорт, зоровий дискомфорт, нерівномірність освітлення і т. д.

Якість архітектури як візуальне мистецтво переважно оцінюється на основі зорових вражень, можливих лише за наявності світла. Сучасний період розвитку суспільства характеризується об'єктивними цивілізованими процесами глобальної урбанізації, внаслідок чого сама архітектура стає причиною порушення стану збалансованості середовища для життєдіяльності людини і причиною екологічної кризи. Відомо, що під дією таких антропогенних факторів, як зниження прозорості атмосфери у зв'язку зі зростанням міст i промисловості, відбуваються зміни інсоляційних ресурсів на селітебних територіях. В рамках концепції урбоекологічного підходу у формуванні середовища життєдіяльності людини, на перший план висуваються проблеми створення комфортної біокліматичної архітектури або екологічних будівель, що дозволяють багатосторонньо використовувати енергію Сонця.

Серед факторів, що визначають якість середовища, важливе місце займає природне світлове середовище, яка багато в чому залежить від характеру світлового клімату. Сонячне світло має всеосяжний вплив на всі основні категорії архітектури, включаючи світлову 
комфортність, довговічність, виразність, економічність. Відповідний рівень і якість освітлення приміщень та урбанізованих територій $є$ важливою передумовою створення світлових комфортних умов життєдіяльності людини, сприяє ii творчій активності, підвищенню продуктивності праці і поліпшенню умов відпочинку. Параметри світлового середовища є одними з основних елементів, які формують мікроклімат приміщень.

У багатьох розвинених країнах у зв'язку з розширенням мегаполісів актуалізується питання не тільки функціональної, але і візуальної естетичної комфортності середовища. Створення світлового середовища, що відповідає практичним, психологічним і естетичним вимогам перебуваючих у ньому людей - це одне 3 найважливіших завдань архітектора. Знання основних композиційних властивостей освітлення, способів його раціонального використання в архітектурі, володіння методичними навичками архітектурного проектування сприяє успішному вирішенню цього завдання. Умови освітленості визначають правильне сприйняття композиційного ритму, пропорцій і глибини приміщень, пластики і кольорової обробки поверхні.

Поняття світлового середовища включає інтегральне узгодження компонентів природного та штучного освітлення, розглянуте в єдності та взаємодії. Прогресивний прийом інтегрального (поєднаного) освітлення диктується соціальної потребою і знаходить відображення в поліпшенні якості освітлення і в економії ресурсів на проектування i будівництво будівель і споруд.

Сучасні досягнення в галузі фундаментальних та природничих наук дозволяють удосконалювати методи і засоби досліджень і прогнозування в пізнанні складної взаємодії людини i середовища. Головним завданням $\epsilon$ оптимізація світлового середовища в архітектурі при раціональному використанні енергетичних і природних ресурсів.

Ключові слова: комфорт, світлове середовище, зоровий комфорт, дискомфорт, принципи світлового утворення форми.

Purpose of the study. Architectural lighting of the interior spaces of residential and public buildings (light comfort).

The objectives of the study. To reveal and analyze the principles of shaping a comfortable light architectural environment for residential and public buildings.

Relevance of the topic. The work is devoted to the identification of the role of artificial light in the "reading" of the architectonics of illuminated buildings and structures and the creation on this basis of a characteristic night image of architectural objects in the city. The study is based on the concept of "tectonics" as the "semantic basis of architectural artistic expressive language", which requires a separate study in the context of the modern approach to artificial lighting of architecture [1].

The art of outdoor lighting of both individual city objects and architectural spaces and ensembles, which has been actively developing throughout the 20th century, has acquired the status of independence in recent years. With growing social demand on the basis of architecture, design and lighting, a new interdisciplinary direction of professional activity was born - lighting design. Its theoretical and methodological foundations are in the initial stage of development. There are rules governing the amount of light on objects in the urban environment and partly the qualitative component of outdoor lighting, however, science does not yet offer ways to translate the amount of lighting into the quality of the light environment. Current regulations are very elementary. The practical design of architectural lighting is dominated by a unitary, intuitive, empirical approach [2].

The absence of recommendations on the conceptual part of outdoor lighting creates chaos and visual discomfort in night cities, which negatively affects the psycho-emotional state of a person, reduces the ecological and aesthetic quality of the architectural environment, negatively affects the city's economy, depriving it of the possibility of rational energy consumption and profit from evening tourism and the revitalization of social life. Today, when the design of artificial 
light takes on an urban scale, i.e. Lighting concepts are being developed not for individual buildings, but for streets, ensembles and cities. The issue of lighting, primarily cultural heritage sites, is as relevant as ever [3].

Historical architecture, as the most important element of national heritage, underlies the morphology of most cities and deserves the right to be recognizable at any time of the day. The image of historical buildings and structures is inextricably linked in our perception with certain conditions of daylight for which they were designed. As a result, a necessary condition for artificial lighting is the preservation of the individual imagery and compositional integrity of the object, in the absence of which visual identification is difficult [4].

The degree of knowledge of the topic. The issue of the influence of light on visual perception and interpretation of architectonics has not been specifically investigated. There are few theoretical works on the role of natural light in the perception of architecture. On this basis, modern concepts of tectonics are formulated. In the field of artificial lighting, to a certain extent, only the visual perception of planning and depth of space, the influence of contrast of lighting on the perception of form, intensity and color of light on emotional assessments, on the visibility and visual comfort of the city's light environment were studied.

The dissertation research is based on works devoted to outdoor lighting, including architectural, as well as on scientific works in the field of lighting engineering, the theory of architecture, sociology, psychology, videoecology, lighting design.

Theoretical and practical issues of lighting are revealed in the writings of I. Azizyan, D. Barnett, D. Benia, A. Danler, N. Gusev, M. Ishii, M. Krauter, K. van Santen, V. Lukkhardt, V. Makarevich, R. Narbopi, D. Neumann, N. Obolensky, D. Phillips, T. Schilke, N. Shchepetkova, F. Yapnone.

Scientific and technical issues of the possibilities of lighting equipment in the field of architectural lighting are reflected in the works of Y. Aizenberg, R. Kelly, B. Köhler, E. Myasoedova, V. Pyatigorsky.

In the field of the theory of color and coloristic of the urban environment, the work is based on the work of I. Goethe, A. Efimov, I. Itten, L. Limanskaya, I. Migalina, L. Mironova, F.-O. Runge, however, not considering issues of perception of architecture in conditions of artificial lighting.

The problems of architectonics in daylight are studied in the works of I. Azizyan, D. Arkin, K. Bettiher, A. Vesnin, Y. Volchka, M. Ginzburg, G. Zemper, A. Ikonnikov, S. Lebedev, O. Munz, Yu. Somov, V. Stepanova, L. Taruashvili, F. Otto, P. Frankl, Y. Chernikhova.

Statement of the main research material. The problem of the optimal use of the solar light energy in architecture covers a wide range of issues that have been studied by many scientists and practitioners, starting from the ancient period of the development of civilization (Hippocrates, Herodotus, Vitruvius and Palladio).

The quality of the light environment depends unconditionally on insolation. The idea of standardizing the quality of the light environment in architectural design arose at the end of the 19th century, when there were no ideas about the relationship between the standardization of the quality of the light environment and the biological effect of the sun. Scientists of the former Union of Socialist Republics developed concrete proposals for urban planning regulation of insolation in the 40 s of the XX century.

The Institute of Natural Lighting in Stuttgart (Germany), as well as a number of other foreign design institutes and organizations are working on the problem of effective sun protection of residential and public buildings. The modes of solar radiation in various regions of the globe are being studied, and the requirements for sun protection measures are being developed.

Among the aggregate studies of the problem of insolation and sun protection in architecture, a number of areas stand out: analytical, theoretical, experimental instrumental, biological and hygienic (bactericidal effect of sunlight), psychological and aesthetic directions. 
Functional (healing and tonic effects) and bactericidal (sanitizing effects) reactions of the light environment are of great practical importance in modern buildings.

Scientists carried out basic research on the bactericidal action of sunlight: V. Belikova, N. Danzig, R. Dmitrieva, A. Zabalueva. D. Lazarev is the author of the idea of "heavenly baths" (comfortable ultraviolet irradiation of a person with natural diffused light from a clear sky). A.Voeikov emphasized the influential role of the sun in the formation of a comfortable human environment (architecture).

Swedish scientists (G.Pleigel, H.Ronge, L.Holm) studied the effect of insolation on the microclimate of interior spaces. The studies were conducted on bacteriological and epidemiological, climatological and sociological aspects.

The psychological role of insolation, using calculation methods using "solar charts", was investigated by: I.Krohman (Germany) and researchers at the Kiel Research Institute. According to their observations, by heating the walls with the Sun, you can save up to $80 \%$ of fuel. In England, lighting technicians E.Nieman and R.Hopkinson developed a scale of psychological responses to indoor insolation conditions.

For the first time in foreign science, the problem of insolation in the whole variety of contradictory relationships of various sides of the influence of the Sun on the formation of the architecture of urban spaces and buildings, rationing and optimization of the parameters of insolation and sun protection was posed and carried out by N. Obolensky.

Textbook A. Rimsi, which is devoted to the problem of urban development in a hot climate. In the training manual N. Shchepetkova formulated the main goals, tasks of architectural artificial lighting (urban spaces and objects) and methods for their implementation based on the proposed light composition system. Book of the candidate of architecture A. Shchipanova is devoted to the study of the architectural and artistic role of artificial lighting in the interior architecture of public buildings.

Richard Saxon (USA) comprehensively investigated the problem of building buildings with free internal space (atrium types of various public complexes, office buildings, hotels, commercial buildings) and, in particular, their lighting and climate control.

Hungarian author J. Koso based on the European experience of low-rise housing construction summarized the results of the analysis of the bio architecture of the turn of the millennium, the so-called "solar houses".

In European countries, depending on the purpose of the premises, the norms of natural lighting are established. From a physiological point of view, natural lighting is most favorable for humans [5]. Nevertheless, since prehistoric times it was necessary to use artificial lighting. And the desire to optimize artificial lighting leads to the need to solve some architectural problems. A significant part of the work and rest of a person takes place under artificial and natural light.

Considering the quality of lighting, it should be noted that the eye perceives light exposure as a scalar value [6]. In nature, objects of relatively equal brightness are constantly found. At the same time, a person distinguishes objects from each other well. In addition to the quantitative characteristics of light, a person perceives and distinguishes his qualitative characteristics. Analyzing the conditions of illumination it is necessary to say that the color of an object can change with changing lighting [7]. Therefore, in those cases where it is important to maintain the unchanged color schemes, for example in art galleries, shops selling textile products, etc., they try to create lighting that is similar in spectral composition to daylight.

Comfortable light intensity is closely related to the color temperature of the source [8]. Apparently, this is due to historical reasons. For thousands of years, people have used fiery light sources for artificial lighting: a bonfire, a torch, a candle, an oil lamp. The lighting was low temperature, the light was low. And in the human mind these characteristics of lighting were firmly connected: at night he put up with a faint, reddish light and considered it bright enough. The day was dominated by bright white (compared to night-blue) light [9]. 
Talking about what is comfort or what is the comfort of a light environment, including in architecture, we can say the following:

COMFORT (Eng. Comfort) convenience, coziness (shelter), cottage, free space, home peace, comfort and excess. Comfortable, deceased, comfortable, cozy, private (Dahl's dictionary).

COMFORT COMFORT, pl. no husband. (Eng. Comfort). A set of household amenities. The apartment is comfortable. He loves peace and comfort. Provide the patient with the necessary comfort (Ushakov's dictionary).

COMFORT a, m. Living and living conditions, conditions providing convenience, tranquility and comfort (Ozhegov's dictionary).

COMFORT (German, English, French Comfort) from St. Franc. Comfort "reinforcement" (Max Fasmer Dictionary).

COMFORT comfort, comfort, convenience, convenience (dictionary of Russian synonyms).

COMFORT (English Comfort), household amenities; the well-being and comfort of homes, public institutions, communications, etc. In a figurative sense: peace of mind is a state of inner peace, the absence of discord with oneself and the world around us (modern explanatory dictionary of the publication "Big Soviet Encyclopedia".

COMFORT a set of amenities, a state of inner satisfaction arising under the influence of any favorable conditions, circumstances, etc. (new dictionary of the Russian language by T.F.Efremov).

LIGHT COMFORT, a favorable lighting environment in the room, created by the optimal choice of natural lighting parameters (http://mirslov.com).

COMFORT (Eng. Comfort) - a set of positive psychological and physiological sensations of a person in the process of his contacts with objects or the environment. The comfort of human life is determined by the characteristics of the environment (light mode, microclimate, temperature and humidity), the perfection of the equipment of the home, workplaces, recreational space, ease of use and aesthetics of household items, work equipment and other subject-spatial forms. Achieving comfort is one of the tasks of creating architectural forms and the entire subject-spatial environment [10].

The interior spaces of residential and public buildings in architectural design are the most important objects for creating a comfortable lighting environment for human life, which meets the requirements of hygiene and culture. The comfort of the light environment should positively or negatively contribute to work, restoration of physical and creative forces and mental health of people [11].

A good, sanitary-hygienic, housing and interiors of public buildings meets the physiological needs of a person. Lighting, soundproofing, temperature should not only contribute to the preservation of health and active life, but also create a feeling of comfort.

Conclusions of the basic material and prospects for further development. The interior spaces in architecture should have optimal natural and art lighting. The set of basic indicators light, thermal, air, acoustic modes of the internal space defines the concept of microclimate. The comfort zone of the light environment is limited for humans by a combination of the effects of natural (in some cases artificial) lighting, temperature, humidity and air velocity. At the same time, illumination, temperature, humidity, air quality and movement, and general air exchange determine a comfortable mode.

Artificial lighting, which aims to respect the architectural features of a building or structure, must take into account its structural and tectonic specificity, which obliges the lighting designer to have not only lighting, but also architectural and artistic education.

Solar radiation, being the main component of the light regime, determines the conditions of light comfort. The size of the light openings determines the natural lighting and temperature conditions in the room. It should be noted that in the internal spaces of residential and public 
buildings, there is a constant effect of unfavorable factors that, with low intensity, affect the general state of health of people, especially children and elderly people.

When designing, it should be borne in mind that objects of wall tectonics with insufficient or excessive brightness contrast seem visually lethargic, inert or decorative, order architecture illusory loses depth, stability, strength, arch-vaulted - visual stability, individuality and expressiveness. The ranges of brightness ratios of the main elements of the architectural composition with the effect of insufficient or excessive contrasts for three tectonic systems are determined.

Promising issues in this study may be studies of the effect of lighting on the perception of architectural objects. The study should be aimed at light-composition schemes and brightness ratios that contribute to the best visual perception of architectural structures. It is necessary to determine the optimal ranges of brightness ratios recommended for use in real design. It is advisable to analyze the emotional assessment of the viewer of various lighting options.

\section{LITERATURE}

1. Vygotsky L. Psihologija isskustva / L.Vygotsky. 3-e izd. - M.: Isskustvo, 1986. - p.70.

2. Marder A., Yevreinov M., Plamenitska O. in. Architektura. Short vocabulary-editor / Edited by A. P. Mardera. - K .: Budivelnik, 1995. - 335 p.

3. Benya J. The profession of Light Design-the road towards regulation / James Benya // PLDC 3rd Global Lighting Design Convention, 19-22 October, 2011 in Madrid/E : Convention Proceedings. Gütersloh : Via-Verlag, 2011.- P. 47-49.

4. Danler A. Building with natural light a symbiosis of light, space and sustainability / Andreas Danler // PLDC 3rd Global Lighting Design Convention, 19-22 October, 2011 in Madrid/E : Convention Proceedings. - Gütersloh : ViaVerlag, 2011. - P. 141-144.

5. Iannone F. Ascona: night light sets made by natural daylight / Francesco Iannone // PLDC 3rd Global Lighting Design Convention, 19-22 October, 2011 in Madrid/E : Convention Proceedings. Gütersloh : Via-Verlag, 2011. - P. 103-105.

6. Chervjiakov M. Tektonicheskij obraz architekturnjgj objekta v uslovijach isskustvennogo osveshchenija: dis. kand. Architektury / Michail Michajlovich Chervjiakov. M., 2012.

7. Goncharov N. Issledovanie zriteknoj rabotosposobnosti pri estestvennom, iskustvennom i sovmeshchennom osveshchenii. - V kn.: Trudy NII strjit. fixiki, 1975.

8. Hyks P., Hraska J. Slnecne ziarenie a budovy. ALFA. Bratislava. 1990.

9. Meshkov V. Osnovy cvetotechniki. -M.-L.: Gos'nergoizdat, 1961.

10. Batova A. Princypy proektirovanija naruznogo osveshchenija architekturnych obektov: dis. . каnd. arhitektury / Anastasija Gennadievna Batova. M., 2012.

11. Light and emotions : exploring lighting cultures : conversations with lighting designers / ed. by Vincent Laganier \& Jasmine van der Pol. 2. ed. -Basel: Birkhauser, cop. 2011. - 415 p. 